\title{
環境効率指標を用いたテレビ会議と出張会議のLCAによる比較* \\ LCA Application Comparing the Eco-efficiency of Telemeetings and Face-to-face Meetings *
}

\author{
森本 涼子 $* *$ ・柴原 尚希*** ・ 後藤 直紀 $* * * * \cdot$ 加藤 博和 $* * * * * *$ \\ By Ryoko MORIMOTO ** • Naoki SHIBAHARA*** • Naoki GOTO **** - Hirokazu KATO *****
}

\section{1.はじめに}

情報通信技術(ICT: Information and Communication Technology)の普及は、流通の効率化や、人・物の移動の 削減により、環境負荷を低減しながら商品や情報の価值 を高め、人々の生活に便利さや安心を与える可能性を有 している。しかしICTの普及は、産業や市民生活全般に 変化をもたらすことを通じて、環境問題に対しても正負 様々な影響を与える。例えば、紙資料の電子化、情報通 信による交通活動の代替、情報処理速度改善による企業 の生産性向上は、社会システムを効率化し、環境負荷を 削減させる可能性を有する。一方で端末やサ一バの増加、 使用電力の増設は、環境負荷増大の要因となる。さらに、 交通活動の減少や業務時間の短縮によって生まれた余娂 時間と費用の利用により、「リバウンド効果」と呼ばれ る新たな環境負荷行動を発生させることも考えられる。

これらの問題に対応した環境評価手法として、評価対 象となる活動の環境負荷をライフサイクル全体で推計す るLife Cycle Assessment (LCA)の手法が適用されるように なってきている ${ }^{1) 2)}$ 。推計方法について、経済産業省の主 導で財団法人産業環境管理協会が「ICTの環境効率評価 ガイドライン」3)を作成し、評価の枠組みや実践例を紹介 した書籍) としてまとめており、ICTの環境評価手法はほ ぼ確立されている。しかしこれらにおいては、電子取引 やテレワークが人や物の移動を代替することによって、 運輸部門の環境負荷排出を削減する可能性があることが 認識されているものの、交通機関利用の評価が固定的な シナリオに依存しており、交通活動に関する検討が概略 にとどまっている。一方、土木計画分野では、ICT導入 に伴う交通活動の変化がもたらす環境負荷削減効果の検 討がほとんど行われていない。

そこで本研究では、旅客交通を代替するICTサービス を取り上げ、その導入が交通活動を代替することによる

*キーワーズ : 地球環境問題、環境計画

**正会員、修(環境)、名古屋大学 大学院環境学研究科

（广464-8603 名古屋市千種区不老町C1-2(651)

TEL : 052-789-3828、E-mail : rmori@urban.env.nagoya-u.ac.jp) ***正会員、修(環境)、名古屋大学 大学院環境学研究科 *****非会員、修(工)、独立行政法人都市再生機構 *****正会員、博(工)、名古屋大学 大学院環境学研究科 准教授
環境負荷変化の定量評価手法をLCAを用いて構築するこ とを目的とする。日本においては、地球温暖化防止策と して旅客交通への取り組みが重要であるとの観点から、 「京都議定書目標達成計画」においても様々な対策が取 り上げられている。その中に、旅客交通の総量自体を削 減する対策の1つとして「テレワーク等情報通信を活用し た交通代替の推進」が掲げられている。これは、在宅勤 務やテレビ会議などの導入を図るものである。このうち、 本研究では交通手段を利用した出張会議を代替できる

「テレビ会議システム」を取り上げ、その導入による環 境負荷削減可能性を検討寸る。

出張会議の評価には、交通システムを対象として開発 されてきたLCA手法5),7)を適用する。一方、テレビ会議 については、その導入に伴う行動変化が環境に与える影 響を、LCAの積み上げ法によって評価する。また、出張 会議とテレビ会議の生産性の違いを考慮に入れ、環境負 荷投入あたりに得られる会議の生産性の值である「環境 効率」 ${ }^{8)}$ での評価を行うとともに、比較にあたっては、環 境効率の比である「ファクター」 ${ }^{9}$ での表示を試みる。さ らに、会議の頻度や出張距離、利用交通手段による環境 負荷の感度分析も実施し、ワークスタイルの違いによっ て環境面から見た最適行動がどう変わるかについても分 析する。

\section{2. 既往研究と本研究の位置付け}

ICT サービス導入による環境負荷変化の LCA による評 価や予測は、大きく(1)環境負荷を積み上げる手法と(2)産 業連関分析等の社会経済全体を評価する枠組みを用いた 手法に分けることができる。本研究では、それぞれ(1)ボ トムアップ型手法、(2)トップダウン型手法と称し、既往 研究の分類を行う。

\section{(1)ボトムアップ型分析手法}

ICT サービスの導入に伴う機器等の追加や使用・維持 に伴う環境負荷の評価には、投入される個々の材料ごと の使用量と各材料の生産に伴う環境負荷を詳細に積み上 げていく分析手法が一般に用いられる。

八木田ら ${ }^{10}$ は、新聞を対象に、インターネット配信導 入により、印刷物を配達する場合と比べて $\mathrm{CO}_{2}$ 排出量が どのように変化するか比較している。松野ら ${ }^{11}$ は、音楽 
ソフトウェアの購入に関わる $\mathrm{CO}_{2}$ 排出量を、従来の $\mathrm{CD}$ 購入による場合とインターネット配信の場合について比 較している。また、高橋ら ${ }^{2)}$ は、出張会議をテレビ会議 で代替する場合や、従来の口座振替契約者への請求書明 細送付(紙媒体)を電子配信によって行う場合の $\mathrm{CO}_{2}$ 排出 量変化を推計している。

ボトムアップ型分析手法では、ICT サービス導入によ って遡及的に生じる環境負荷として、そのために投入さ れる資材・エネルギーを詳細に調べ上げ、その環境負荷 を積み上げていくため、環境影響の詳細な分析が可能と なる。推計結果は設定された評価範囲に依存するため、 その設定の仕方が問題となってくるが、設定の妥当性に ついては、必要に応じてその設定を変化させた場合の感 度を分析することで検討できる。また、リバウンド効果 や社会への波及効果に関しても分析が可能ではあるが、 評価範囲の設定に基淮はなく、範囲を広げることによっ て精度や分析手法に関して様々な問題が生じることから、 既往研究ではそれらを除外・限定して評価を行っている ことが一般的である。

(2)トップダウン型分析手法

ICT サービス導入が社会経済システムにまで波及する 影響を評価する場合には、産業連関分析や応用一般均衡 分析といったトップダウン型分析手法を用いることが一 般的である。

松本ら ${ }^{12}$ は、1995 年産業連関表を用いた応用一般均衡 分析により、ICT 普及シナリオによる国の経済構造の変 化を分析し、環境影響を推計している。また、高橋ら ${ }^{2)}$ は、社会全体の情報通信分野を 6 つにカテゴリー分けし、 各カテゴリーのエネルギー消費量の変化量を各種白書や 産業連関表を用いて推計している。

これらの手法では、地域や国といった単位で経済シス テム全体に波及的に生じる影響を包括することができる。 しかし、分析単位が経済統計や産業連関表で用意されて いる粗い財・サービスの区分とならざるを得ないため、 ICT サービス導入による影響のような、より詳細な区分 が必要な分析には適していない。また産業連関表は、更 新頻度が 5 年と長い上に、新しいデータが公表されるの が遅く、技術革新の目まぐるしい情報通信産業の最新技 術動向が反映されにくい。

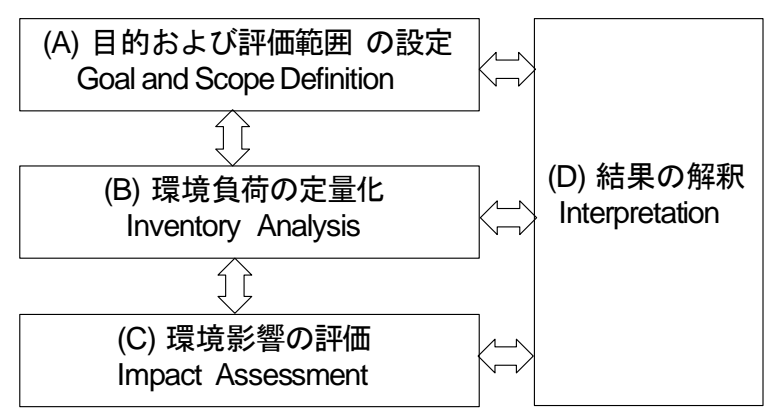

図-1 一般的な LCA の実施枠組み

以上の既往研究を踏まえ、本研究においては、テレビ 会議システム導入の環境面からの評価を詳細に行うため に、ボトムアップ型分析手法である LCA を用いる。その 際、既往研究 ${ }^{2)}$ で行われてこなかった、出張会議におけ る交通機関利用や距離の違いを詳細に分析する。さらに、 導入に伴う行動変化はもとより、リバウンド効果を含め、 導入によって社会経済システムに波及的に生じる環境影 響についても評価を行うこととする。

\section{ICT サービスと交通活動の環境効率算出の方法論}

(1)LCA の一般的な方法論

LCA の一般的な実施枠組みは図-1 に示寸ように、 ISO14040 において規格化されている。まず、LCA 実施 の目的やデータ制約に合うように、調査範囲である「評 価バウンダリ」と、代替案比較のベースを合わせるため の「機能単位」を設定する(A)。次に、各種の資源・エネ ルギー投入量や環境負荷物質排出量を推計する(B)。その 結果をもとに、環境影響の大きさを評価する(C)。最後に 以上の結果の整合性を確認し、分析結果を解釈する(D)。 この枠組みに則り、本研究の対象についていかなる検討 を実施したかについて、次節以降で述べる。

なお、本研究では、評価する環境負荷物質として二酸 化炭素 $\left(\mathrm{CO}_{2}\right)$ の夕を扱い、(C)にあたる環境影響評価は行 わない。

(2)評価範囲の設定(Goal and Scope Definition)

a)機能単位の設定

会議 1 回分に割り当てられる環境負荷を求め、出張会

表-1＼cjkstart評価バウンダリの設定

\begin{tabular}{|c|c|c|c|c|}
\hline \multicolumn{2}{|c|}{ 評価バウンダリ } & 対象とする活動 & (A)出張会議 & (B)テレビ会議 \\
\hline \multirow{5}{*}{ ELCEL } & \multirow{5}{*}{ SyLCEL } & 交通機関利用 & 交通インフラ(利用のみ) & - \\
\hline & & テレビ会議システム & - & テレビ会議端末機器・モニタ・通信回線 \\
\hline & & 会議の付随活動 & $\begin{array}{c}\text { 紙資料 } \\
\text { 飲料・弁当 }\end{array}$ & 紙資料 \\
\hline & & リバウンド効果 & - & 余剰時間の活動(利用のみ) \\
\hline & & 社会への波及 & - & 交通機関の需要減少による運行本数の削減 \\
\hline
\end{tabular}


議とそれをテレビ会議で代替した場合を比較する。

b)評価バウンダリの設定

評価範囲を表-1 にまとめる。会議に直接関わる活動と して、交通システム・テレビ会議システム・紙資料・飲 料・弁当のライフサイクル全体を含める。また、リバウ ンド効果として、余剰となった時間に別の活動を行うこ とで発生する環境負荷を評価する。これらの評価範囲全 体で生じる環境負荷を「システムのライフサイクル環境 負荷(System Life Cycle Environmental Load : SyLCEL)」と 呼び、その值を推計する。

1 回の出張をテレビ会議で代替した場合、自動車利用 であれば移動がなくなることで自動車が利用されなくな り、その分環境負荷は減少する。一方、公共交通機関利 用では、1 人が乗車(搭乗)をやめただけでは、その運行本 数は減らず、移動による環境負荷は削減されないため、 社会全体ではテレビ会議を行った分だけ環境負荷は増大 する。ところが、SyLCEL の推計においては、対象とす る会議 1 回に割り当てられる環境負荷をその活動の積み 上げから求めるため、社会全体で増大しているにも関わ らず SyLCEL は減少するという逆の結果になってしまう。 ただし、テレビ会議の普及が進み、交通機関利用の需要 が減っていくことにつながれば、運行本数が削減され、 その分の環境負荷が削減される。このような交通システ ム自体が変化することによる環境負荷変化分は SyLCEL の範囲では評価されないため、そこまでを範囲に含めた

「拡張ライフサイクル環境負荷(Extended Life Cycle Environmental Load : ELCEL)」 ${ }^{13)}$ による評価・比較も行う ことにする。

(3)インベントリ分析(Inventory Analysis)に用いたデータ a)出張会議における利用交通機関

出張会議における各交通機関利用時の環境負荷は、表-

2 に示寸輸送人 $\mathrm{km}$ ベースの原単位を用いて算出する。 ただし、ELCEL の推計においては、運行本数の削減によ る $\mathrm{CO}_{2}$ 削減を評価する必要があるため、輸送人 $\mathrm{km}$ ベー スの原単位を、混雑率の值を仮定して車両(機体)km あた りの原単位に直して推計に用いる。

b)テレビ会議システム

テレビ会議システムの利用による環境負荷は、産業環 境管理協会が報告した值 ${ }^{14)}$ を用いる。ここではテレビ会 議端末機器・25 インチモニタ・通信回線の製造・使用・ 廃棄段階を評価に含めている。4 章での分析に合わせ、

週 1 回(1 回あたり 2 時間)の使用を想定した場合の LCI(Life Cycle Inventory analysis)結果を図-2 に示す。

c)会議に付随寸る負荷要因

会議に付随して消費するものとして紙資料を、出張会 議の夕に付随して消費するものとして飲料・弁当を取り 上げる。各々の環境負荷原単位に高橋ら ${ }^{15)}$ が推定した消
表-2 各交通機関利用時の環境負荷排出原単位

\begin{tabular}{|c|c|c|c|c|}
\hline 交通機関 & 自動車 & 鉄道 & 新幹線 & 航空機 \\
\hline $\begin{array}{c}\mathrm{CO}_{2} \text { 排出量 } \\
{\left[\mathrm{g}^{-\mathrm{CO}_{2}} \text { 人 } \mathrm{km}\right]}\end{array}$ & 154 & 48 & 20 & 175 \\
\hline 出典 & $\begin{array}{l}\text { 経済産 } \\
\text { 業省 }^{5)}\end{array}$ & 長田ら & \multicolumn{2}{|c|}{$\begin{array}{c}\text { 鉄道総合技術 } \\
\text { 研究所 }^{7)}\end{array}$} \\
\hline
\end{tabular}

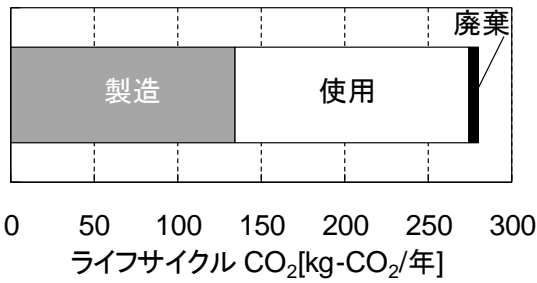

図-2 テレビ会議システムの LCI 結果

表-3 余剩時間の行動分類之環境負荷要因

\begin{tabular}{|c|c|c|c|}
\hline 大分類 & 中分類 & 小分類 & 環境負荷要因 \\
\hline \multirow{2}{*}{$\begin{array}{l}\text { 拘束 } \\
\text { 行動 }\end{array}$} & \multicolumn{2}{|c|}{ 他の仕事 } & パソコン \\
\hline & \multicolumn{2}{|c|}{ 新たなテレビ会議 } & $\begin{array}{l}\text { テレビ会議 } \\
\text { システム }\end{array}$ \\
\hline \multirow{12}{*}{$\begin{array}{l}\text { 自由 } \\
\text { 行動 }\end{array}$} & 会話・交際 & 会話・交際 & 交通 \\
\hline & & スポーツ & 交通 \\
\hline & レジャー & 行楽・散策 & 交通 \\
\hline & 活動 & $\begin{array}{c}\text { 趣味・娛楽・ } \\
\text { 教荃 }\end{array}$ & 交通 \\
\hline & & テレビ & テレビ \\
\hline & & ラジオ & ラジオ \\
\hline & マス & 新聞 & なし \\
\hline & メディア & 雑誌・マンガ & なし \\
\hline & 接触 & 本 & なし \\
\hline & & 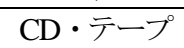 & プレイヤー \\
\hline & & ビデオ & プレイヤー \\
\hline & 休息 & 休息 & なし \\
\hline
\end{tabular}

費量を乗じて積み上げる。

d)リバウンド効果

テレビ会議導入による移動時間の短縮によって生まれ た余剩時間の活動に伴う環境負荷を、リバウンド効果 ${ }^{16}$ として扱う。その推計のためには、まず余唾時間に行わ れる活動を特定する必要がある。本研究では NHK 国民 生活時間調査 ${ }^{17)}$ による、1 日に人がとる行動の調査結果 を利用して余剰時間の使途を仮に想定する。この調査結 果では、余剩時間の行動が表-3 のように分類されている。 これに加えて、各項目の環境負荷要因について合わせて 整理を行った。

余㮃時間のうちの拘束行動と自由行動の割合は高橋ら 15)のアンケート結果を用いる。さらに自由行動の中での 各項目の割合は NHK 国民生活時間調査による 1 日に人 がとる行動の調査結果から、自由時間の変化量と行動時 
間の割合の分布を得て、ICT 導入により増加した自由時 間にとる各行動の平均所要時間の割合を求める。これら の割合を余剰時間に乗じて、各行動の所要時間の期待值 として用いる。以上より、単位時間あたりのリバウンド 効果を推計し、それに余剩時間を乗じて積み上げる。

リバウンド効果の各環境負荷要因による環境負荷排出 量推計方法は、以下の式(1)〜(3)の通りである。

i )パソコン・テレビ・ラジオ・プレイヤー

\{各機器の使用による $\mathrm{CO}_{2}$ 排出量 $\}$

$=\left\{\right.$ 使用端電力 $\mathrm{CO}_{2}$ 排出原単位 $\left.\left[\mathrm{kg}-\mathrm{CO}_{2} / \mathrm{kwh}\right]\right\} \times\{$ 消費電

力 $[\mathrm{kw}]\} \times\{$ 使用時間 $[\mathrm{h}]\}$

平均消費電力は2005年の各社カタログより算出し、使 用端電力による $\mathrm{CO}_{2}$ 排出原単位は、0.378 $\left[\mathrm{kg}-\mathrm{CO}_{2} / \mathrm{kwh}\right]$ を 用いる ${ }^{18)}$ 。

ii)テレビ会議システム

\{テレビ会議システムによる $\mathrm{CO}_{2}$ 排出量 $\}$

$=\left\{\right.$ テレビ会議システム利用の 1 時間あたりの $\mathrm{CO}_{2}$ 排

出量 $\left.\left[\mathrm{kg}-\mathrm{CO}_{2} / \mathrm{h}\right]\right\} \times\{$ 使用時間 $[\mathrm{h}]\}$

テレビ会議システム利用の $\mathrm{CO}_{2}$ 排出量は、図-2 に示し た推計結果を 1 時間あたりに換算する。

iii)交通

\{交通機関の利用に伴う $\mathrm{CO}_{2}$ 排出量 $\}$

$=\left\{\right.$ 人 $\mathrm{km}$ あたりの移動 $\mathrm{CO}_{2}$ 排出量 $\left[\mathrm{g}-\mathrm{CO}_{2} /\right.$ 人 $\left.\left.\mathrm{km}\right]\right\} \times\{$ 人 数 $[$ 人 $]\} \times\{[$ 往復走行距離 $[\mathrm{km}]\}$

移動に伴う $\mathrm{CO}_{2}$ 排出量は、交通関係エネルギ一要覧 ${ }^{19)}$ の值を用いる。移動手段については、三大都市圈別の輸 送機関分担率で加重平均し、移動による平均的な $\mathrm{CO}_{2}$ 排 出量を求める。移動距離には、平成 11 年パーソントリッ プ調査 ${ }^{20)} の$ 三大都市圈の「私用」目的の平均移動距離を 用いる。

\section{(4)環境効率での評価}

環境効率での評価を行うためには、各代替案の性能を 定義し定量化する必要がある。本研究では性能を、会議 に要する時間(移動時間を含む)あたりに得られる成果(会 議の生産性)と捉える。

テレビ会議による出張会議の代替は、移動時間短縮と いうメリットの一方で、非対面によって会議の生産性が 低下するというデメリットがある。NTT 環境エネルギー 研究所は、会議の生産性を問題解決能力で定義し、これ が Achievement、Comfort、Satisfactionの 3 項目の積であ ると定式化している。その上で、Web アンケートによっ て調査した結果から、出張会議の生産性指標を 1 とする と、テレビ会議の生産性指標が 0.63 であることを示して いる ${ }^{21)}$

本研究では、この生産性指標と、表-4 の所要時間設定 を用いて、出張会議 1 回分を機能単位と仮定した、環境 効率を表現する方法を試みる。環境効率を式(4)のように
表-4 各代替案における所要時間の設定

\begin{tabular}{|c|c|c|c|c|c|}
\hline \multirow{3}{*}{$\begin{array}{c}\text { 所要時間 } \\
\text { [時間] }\end{array}$} & \multicolumn{4}{|c|}{ (A)出張会議 } & \multirow{3}{*}{$\begin{array}{l}\text { (B) } \\
\text { テレビ } \\
\text { 会議 }\end{array}$} \\
\hline & \multicolumn{2}{|c|}{ 近距離(30km 以内) } & \multicolumn{2}{|c|}{ 長距離(東京-大阪) } & \\
\hline & $\begin{array}{l}\text { (A-1) } \\
\text { 自動車 }\end{array}$ & $\begin{array}{l}(\mathrm{A}-2) \\
\text { 鉄道 }\end{array}$ & $\begin{array}{c}(\mathrm{A}-3) \\
\text { 新幹線 }\end{array}$ & $\begin{array}{c}\text { (A-4) } \\
\text { 航空機 }\end{array}$ & \\
\hline $\begin{array}{c}\text { 往復移動 } \\
\text { 時間 }\end{array}$ & $\begin{array}{c}\text { 距離/ } \\
\text { 速度 } \\
(32 \mathrm{~km} / \mathrm{h})\end{array}$ & $\begin{array}{c}\text { 距離/ } \\
\text { 速度 } \\
(40 \mathrm{~km} / \mathrm{h})\end{array}$ & 6 & 4 & 0 \\
\hline 会議時間 & 2 & 2 & 2 & 2 & 2 \\
\hline 合計 & $\begin{array}{c}\text { 距離/32 } \\
+2\end{array}$ & $\begin{array}{c}\text { 距離/40 } \\
+2\end{array}$ & 8 & 6 & 2 \\
\hline
\end{tabular}

※テレビ会議に代替した場合に生じる余剩時間=出張会議の往復移動時間

定義する。環境効率は、単位環境負荷あたりの性能 ${ }^{8)}$ で あり、本研究では会議の性能を、単位時間あたりの会議 の生産性としている。

$$
\text { 環境効率 }=\frac{\text { 会議の生産性指標 } / \text { 必要時間 }}{\text { 環境負荷 }}
$$

さらに、代替案間の環境効率比であるファクターは式 (5)のように定義される。ファクターが 1 を超えれば、現 状より環境効率が向上寸ることを意味する。

$$
\text { ファクター }=\frac{\text { 代替案(テレビ会議)の環境効率 }}{\text { 現状(出張会議)の環境効率 }}
$$

\section{(5)結果の解釈(Interpretation)}

推計される值は、本研究で設定した仮定のもとでの結 果であり、その設定が実際とそぐわないこともむろんあ り得る。そこで、会議開催頻度や出張距離が変化したと きの結果の変動を感度分析によって明らかにする。それ により、条件による環境負荷の違いも併せて分析寸る。

\section{4. テレビ会議・出張会議比較への適用}

\section{(1)シナリ才設定}

ある会社の本社の社員数名と支社の社員 1 名が参加す る 2 時間の会議を想定する。代替案は、以下の $(\mathrm{A}) 、(\mathrm{~B})$ の 2 種類である。
(A)支社の社員が本社まで出張して会議を行う
(B)出張せずにテレビ会議を行う

テレビ会議システムの設定として、25 インチモニタが 両地点にあるものとする。会議頻度は週 1 回とする。一 方、出張会議における移動は、近距離の場合は(A-1)自動 車もしくは(A-2)鉄道で、遠距離の場合は(A-3)新幹線もし くは(A-4)航空機で行われるものとする。 
(2)近距離出張会議代替の評価

自動車や鉄道の利用が前提となる都市圈内の出張会議 について、テレビ会議による代替が、会議あたりの SyLC-CO $\mathrm{CO}_{2}\left(\mathrm{SyLCEL}\right.$ で評価した $\left.\mathrm{CO}_{2}\right)$ を削減させ得るか砮 かを評価する。

各出張距離における $\mathrm{SyLC}-\mathrm{CO}_{2}$ 推計結果を図-3 に、会 議の生産性・時間節約を考慮したファクターを図-4 に示 す。自動車を利用する出張会議(A-1)の場合、SyLC-CO では、 $18 \mathrm{~km}$ 以遠の出張会議はテレビ会議で代替する方が 小さくなる。ファクターは $12 \mathrm{~km}$ 以遠で 1 以上となり、 SyLC- $\mathrm{CO}_{2}$ の場合よりもテレビ会議に有利な結果となって いる。これは、テレビ会議に代替することで会議の生産 性は下がるものの、移動時間を削減することで、環境効 率が向上するためである。一方、鉄道を利用する出張会 議(A-2)の場合では、想定した $30 \mathrm{~km}$ 以内であれば出張会 議のままの方が $\mathrm{CO}_{2}$ が排出量が小さく、テレビ会議に代 替すると環境効率が低下しファクターが 1 未満になって しまう。

\section{(3)長距離出張会議代替の評価}

新幹線・航空機利用となる長距離移動を伴う出張会議 について、テレビ会議導入による代替が環境負荷を削減 させ得るのかを評価する。

各利用交通機関における所要時間の設定を表-4 に示す。 支社・本社の位置は、それぞれ新大阪駅・東京駅から徒 歩圈であると仮定し、その端末交通の所要時間は、都市 交通年報(平成 19 年版) ${ }^{22}$ に示されている平均所要時間を 参考に 1 回あたり 10 分とする。

会議 1 回あたりに割り当てられる $\mathrm{SyLC}-\mathrm{CO}_{2}$ を推計し た結果を図-5に示す。テレビ会議(B)の場合は、新幹線利 用による出張会議(A-3)、航空機利用による出張会議(A-4) のいずれよりも小さくなっている。また、本研究におけ るリバウンド効果の推計は簡略的なものであるが、

SyLC- $\mathrm{CO}_{2}$ に占めるリバウンド効果や弁当・飲料などが占 める割合は小さいため、大部分を占めるテレビ会議シス テムおよび交通システムに関する分析が重要であること が示された。

次に環境効率の推計結果をファクターで図-6 に示す。 新幹線による出張(A-3)、航空機による出張(A-4)のいずれ の場合も、テレビ会議(B)で代替することでファクターが それぞれ 7、37 となり、環境効率が大幅に向上する。ま た、近距離での会議にテレビ会議を導入する場合よりも、 環境効率の向上がより顕著である。

\section{(4)会議開催頻度による感度分析}

ここまでは、会議開催頻度(テレビ会議の場合、設備利 用頻度となる)を週 1 回と設定していた。そこで、東京一 大阪間という想定はそのままで、頻度を変化させた場合

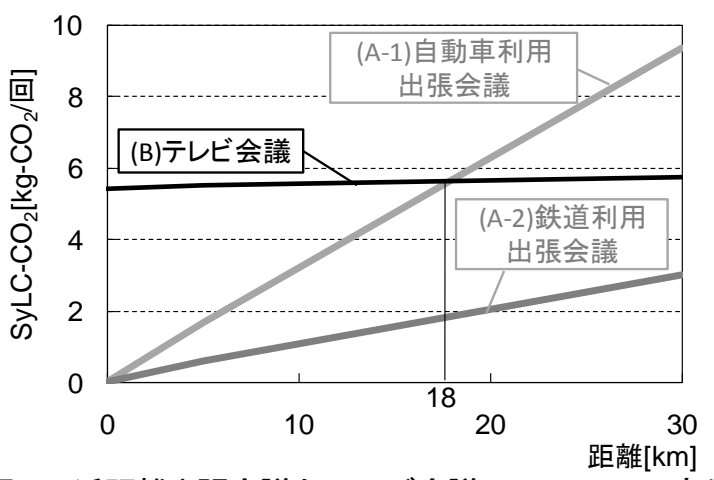

図-3 近距離出張会議とテレビ会議の SyLC-CO $\mathrm{CO}_{2}$ 変化

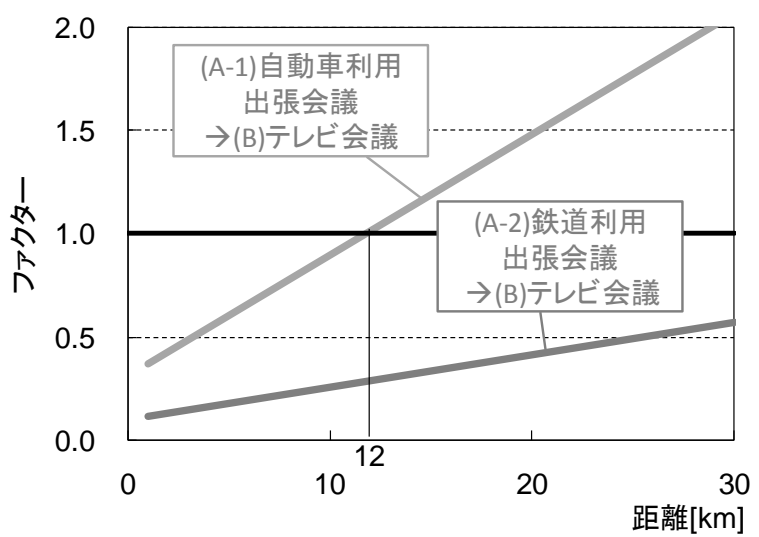

図-4 近距離会議の距離によるファクター変化

\begin{tabular}{|ll|}
\hline $\begin{array}{l}\square \text { 交通システム } \\
\text { 紙資料 } \\
\square \text { リバウンド効果 }\end{array}$ & $\begin{array}{l}\text { ロテレ゙会議システム } \\
\text { 弁当·飲料 }\end{array}$ \\
\hline
\end{tabular}

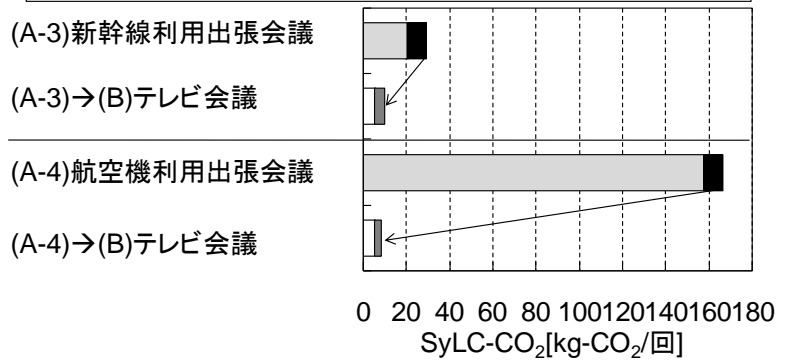

図-5 長距離出張会議の SyLC-CO 2 推計結果

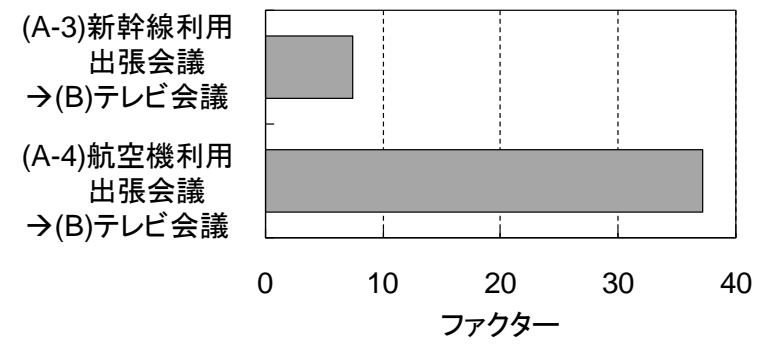

図-6＼cjkstart長距離会議のファクター推計結果 
の感度分析を行う。SyLC-CO 2 について図-7、ファクター について図-8に示す。

会議開催頻度週 1 回(年間 52 回)の前後に注目すると、 頻度の変動によって機能単位(会議 1 回)あたり $\mathrm{SyLC}-\mathrm{CO}_{2}$ に大きな変化はみられず、テレビ会議の $\mathrm{SyLC}^{-\mathrm{CO}_{2}}$ が最 も小さいことが分かる。ただし、年間若干回しか会議を 行わない場合は、テレビ会議システム自体に起因する $\mathrm{CO}_{2}$ の会議 1 回に割り当てられる分が大きくなることか ら、新幹線を利用した出張会議の方が SyLC-CO 2 が少な くなる。ファクターの変化も同様の傾向がみられるが、 年間会議開催回数が少なくても、移動時間が削減される ため、ファクターは 1 以上となっている。

(5)出張距離による感度分析

新幹線利用の長距離出張会議において、出張距離を短 くした場合を設定し、テレビ会議で代替した場合の環境

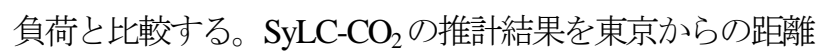
の関係と併せて図-9 に示す。また、ファクターの推計結 果を図-10 に示寸。

この結果から、東京一新横浜間 $(25.5 \mathrm{~km})$ という短距離 であっても、新幹線利用の出張会議に比ベ、テレビ会議 の方が会議 1 回に割り当てられる $\mathrm{SyLC}-\mathrm{CO}_{2}$ が小さく、 ファクターが 1.8 以上であることが分かる。また、出張 距離が長くなるほど、移動を取りやめる場合のリバウン ド効果も大きくなるため、テレビ会議の SyLC- $\mathrm{CO}_{2}$ は距 離によって増大寸るが、新幹線走行分による出張会議の SyLC- $\mathrm{CO}_{2}$ 増大の寄与の方が大きいため、ファクターは向 上する。

\section{5. 交通システムの変化を含んだ ELCEL 推計結果}

4 章で推計した会議 1 回あたりの SyLCEL は、会議に 環境負荷を配分した結果であり、社会全体の環境負荷が どう変化したかは表現していない。ここでは、新幹線を 利用した出張会議を対象として、テレビ会議普及によっ て運行本数の変化が生じることも含めて評価した ELCEL を算出する。評価範囲は、SyLCEL で対象とした会議に 関する活動とリバウンド効果に加えて、東京一大阪間の すべての新幹線の運行を含め、1 日あたりの環境負荷排 出量を比較する。

平成 $11 \sim 16$ 年度の東海道新幹線の 1 日あたり運行本数 と実績輸送人 $\mathrm{km}$ の関係データから、1 日の輸送人 $\mathrm{km} の$ うち 146 万人 $\mathrm{km}$ を削減これを東京一大阪間で換算する と出張人数 1,417 人の削減)することによって、東海道新 幹線の運行本数を往復 1 本減らすことができると仮定す る。

これを用いて、テレビ会議普及に伴う出張人数減少が $\mathrm{CO}_{2}$ 排出量削減をもたらす効果を推計する。その結果を、

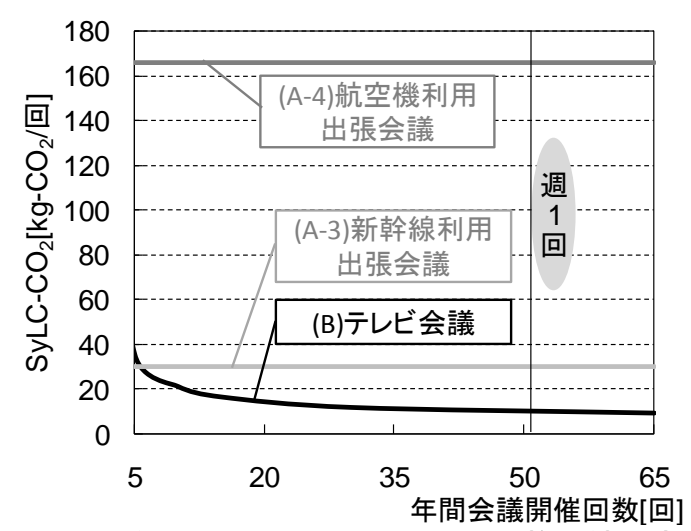

図-7 会議開催頻度による SyLC-CO 2 推計值の変化

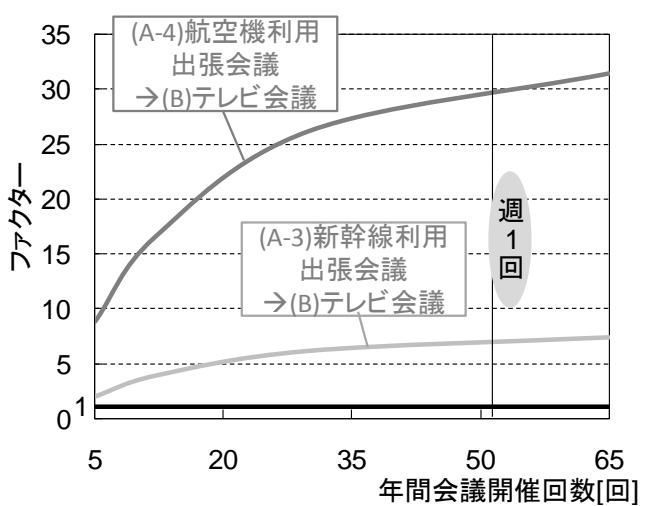

図-8＼cjkstart会議開催頻度によるファクターの变化

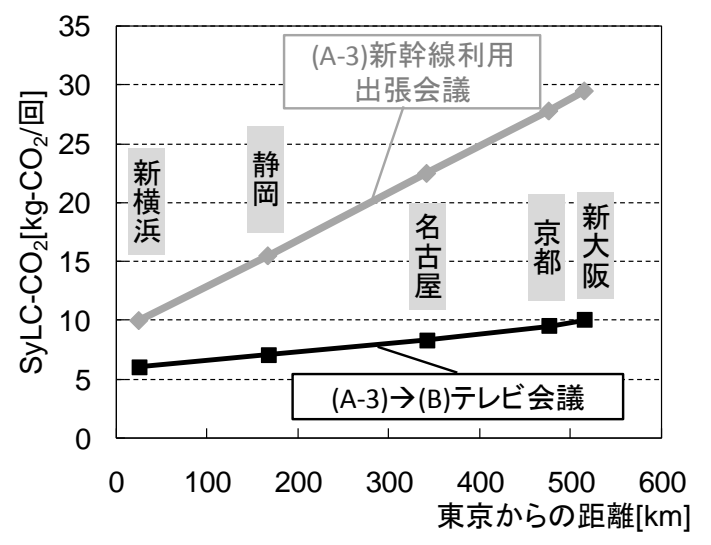

図-9 出張距離による SyLC-CO 2 推計值の変化

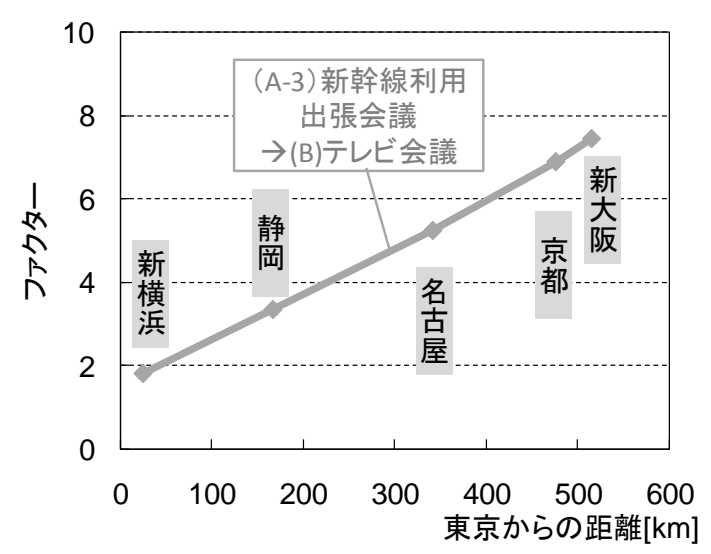

図-10＼cjkstart出張距離によるファクターの変化 
テレビ会議普及量と $\mathrm{ELC}-\mathrm{CO}_{2}$ (ELCEL で評価した $\mathrm{CO}_{2}$ 排 出量)変化の関係として図-11 に示す。この図では、週 1 回開催の設定を、1 日 1 回に変化させたときの推計結果 も合わせて表示している(図の点線)。なお、ELCEL 推計 では機能に対して環境負荷を考慮するバウンダリが大き 寸ぎ、環境効率を考えることができないため、ファクタ 一の推計は行っていない。

SyLC- $\mathrm{CO}_{2}$ 推計において明らかにしたように、テレビ会 議が普及すると、出張会議で必要であった弁当・飲料が 削減される一方で、テレビ会議システム利用の $\mathrm{CO}_{2}$ 排出 量が増加するため、普及が少ない場合は、どちらが $\mathrm{CO}_{2}$ 排出量が大きいかは会議頻度に依存する。しかし、テレ ビ会議の普及量が大きくなり、新幹線の需要が削減され れば、出張会議よりテレビ会議の方が ELC-CO 2 は小さく なる。運行本数は自然数であるため、新幹線の需要減に 応じて ELC-CO 2 は階段状に削減される。また、会議頻度 が高いほど、1 回の会議に割り当てられるテレビ会議シ ステムの環境負荷が小さくなることから、週 1 回の開催 よりも 1 日 1 回会議を行う場合にテレビ会議を導入する 方が、環境負荷削減量は大きくなる。その感度は、新幹 線運行本数削減の感度と比べても、小さくないことが示 された。

\section{6. おわりに}

本研究では、交通行動の削減をもたらす ICT 技術の例 として、テレビ会議システムの導入による環境負荷削減 可能性を、従来の出張会議と比較する方法をLCA を用い て構築し、ケーススタディを実施した。それによって得 られた知見として、次のことが挙げられる。

i) リバウンド効果は $\mathrm{SyLC}-\mathrm{CO}_{2}$ に影響を与えない程度 であり、むしろ交通システムやテレビ会議システム の分析の方が重要である。

ii）鉄道や自動車を利用する出張会議は、近距離の場合 テレビ会議で代替しない方が会議に配分される SyLC-CO ${ }_{2}$ が小さくなる場合もある。

iii）新幹線や航空機を利用する長距離の出張会議の場合、 テレビ会議に代替した方が会議に配分される SyLC$\mathrm{CO}_{2}$ が小さくなり、環境効率も向上寸る。

iv）社会全体にテレビ会議普及の動きが広まり、新幹線 の本数を減少させるまでに至った場合は、出張会議 よりも ELC-CO 2 を抑えられる。

本研究では現状の社会システムを出発点としているた め、すでに存在している交通機関の利用のみを対象とし ているが、鉄軌道の新規整備を代替案とする場合には、 その建設に伴う環境負荷の考慮が必要となるため、より テレビ会議に有利な結果となると予想される。

本研究のすべての結果は、想定される会議の規模や頻

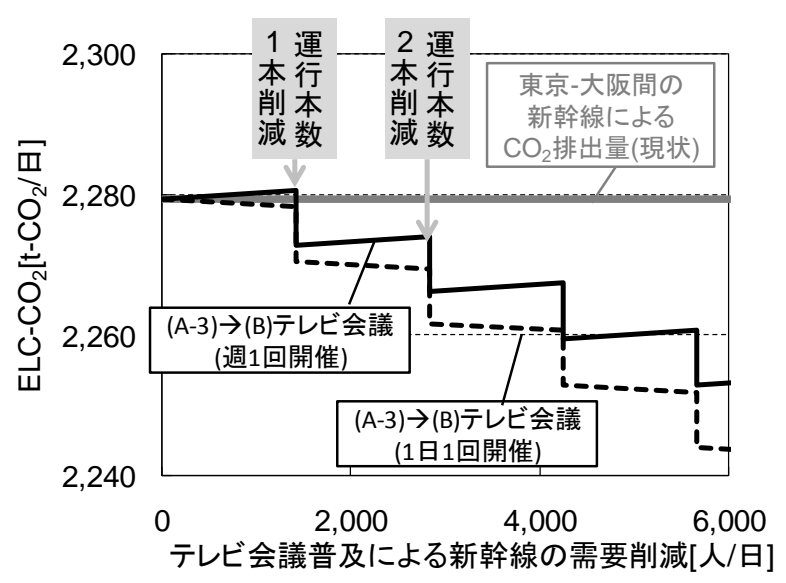

図-11 テレビ会議普及量と ELC- $\mathrm{CO}_{2}$ の関係

度、出張距離等によって変化することは言うまでもない。 本研究ではボトムアップ型分析手法を用いているため、 設定を変化させた場合の結果の違いを感度分析によって 明らかにすることができる。また、個別に追加的な調査 等でより確実な設定值を見出すことで、結果の信頼性を 向上させることも可能である。

謝辞: 本研究は科学研究費・萌芽研究(19651016)の助成 を受けたものである。また、研究の遂行にあたり、NTT 環境エネルギー研究所の高橋和枝様に多大な協力を頂い た。ここに記して謝意を表す。

\section{参考文献}

1) 西史郎 : ICT の環境影響と環境負荷肖減〜評価手法と NTT の取組み， 日本LCA 学会第6回LCA 講演会「LCA 的観 点でのICT のグリーン社会への役割」資料, 2008.

2）高橋和枝，中村二郎，津田昌幸，立道英俊，西史郎：情報 通信(ICT)サービスの環境効率 : 日本 LCA 学会誌, Vol.1,

No.3, pp.213-220, 2005.

3）社団法人産業環境管理協会: 平成 17 年度情報通信技術 (ICT)の環境効率評価ガイドライン, 2005.

4）松野泰也，近藤康之編著：IT 社会を環境で測る一グリーン 物流一, 社団法人産業環境管理協会, 丸善, 2007.

5) 経済産業省環境調和産業推進室 : LCA プロジェクトの現状 と今後の在り方, LCA 日本フォーラム LCA プロジェクト 報告会資料， 2007.

6）長田基広，渡辺由紀子，柴原尚希，加藤博和：LCA を適用 した中量旅客輸送機関の環境負荷評価, 土木計画学研究 論文集, Vol.23, No.2, pp.355-363, 2006.

7) 鉄道総合技術研究所 : 鉄道総研報告, Vol.16, No.10, 2002.

8) L. D. DeSimone, F. Popoff, 山本良一監訳 : WBCSD, エコエ フィシェンシーへの挑戦; 持続可能発展のための産業界の リーダーシップ，日科技連出版社，1998. 
9) E.U. von Weizsacker, A.B. Lovins, and L.H. Lovins, 佐々木健 訳 : ファクター4一豊かさを 2 倍に, 資源消費を半分に, 財 団法人省エネルギーセンター，1998.

10）八木田浩史, 田原聖隆, 玄地裕, 稲葉敦, 松野泰也 : IT 化 の進展に伴う情報配信に関わる $\mathrm{CO}_{2}$ 排出量の変化可能性の 評価一ネット配信型新聞についてのケーススタディーー, MACRO REVIEW, Vol.15, No.1, pp.9-18, 2002.

11）松野泰也, 玄地裕, 八木田浩史, 稲葉敦, 佐竹一基, 森浩 之, 冨田秀実 : 情報化技術(IT)の導入による電力消費量お よび $\mathrm{CO}_{2}$ 排出量の削減効果一インターネットを利用した音 楽配信と既存の CD を媒体とした音楽配信の比較評価厅ー ススタディ一，日本エネルギー学会誌 82, pp.57-63， 2003.

12）松本光崇, 入江康子 : IT システムの環境影響評価, NEC 技 報, Vol.57, No.1, pp.69-72, 2004.

13）加藤博和 : 交通分野へのライフサイクルアセスメント適用, IATSS Review, Vol.26, No.3, pp.55-62, 2001.

14）産業環境管理協会 : LCA 日本フォーラムニュース 35 , pp.7-8, 2005.

15）高橋和枝, 國岡達也, 加藤清, 立道英俊, 田中融, 西史 郎 : IT サービスが人々のライフサイクルに与える影響とそ の環境負荷, エコデザイン 2004 ジャパンシンポジウム論文 集, pp.46-47, 2004.
16) Lorna A. Greening, David L. Greene, Carmen Difiglio : Energy efficiency and consumption - the rebound effect - a survey, Energy Policy, Vol.28, No.6-7, pp.389-401, 2000.

17） NHK放送文化研究所 : 日本人の生活時間 2000, 2001.

18）環境省地球環境局 : 地球温暖化対策の推進に関する法律施 行令, 2002 .

19）国土交通省総合政策局情報管理部 : 交通関係エネルギー要 覧平成 17 年版, 2005.

20）国土交通省 : 平成 11 年全国都市パーソントリップ調査集計 結果, 1999 .

21) Kazue Takahashi, Masayuki Tsuda, Tatsuya Kunioka, Jiro Nakamura, and Shiro Nishi : Environmental Assessment of Videoconference -New Assessment Methodology for ICT Services Considering Ripple Effects and Performance Indicators, Towards Sustainable Product Design $10^{\text {th }}$ International Conference, 2005.

22）財団法人運輸政策研究機構 : 平成 19 年度版都市交通年報, p.41, 2008.

\section{環境効率指標を用いたテレビ会議と出張会議の LCA による比較*}

森本 涼子** - 柴原 尚希*** - 後藤 直紀**** - 加藤 博和******

ICT サービス導入は、交通活動による環境負荷を削減する可能性がある。本研究では、テレビ会議が出張会 議を代替することによる環境負荷削減・環境効率向上の可能性を、LCA を用いて検討する。環境負荷増大要因 となる、会議に付随する活動やテレビ会議導入によって生じる余剰時間の行動も評価対象とし、交通機関利用 に関するいくつかの要因についての感度分析によって詳細に分析する。その結果、近距離出張であれば、鉄道 利用や短距離自動車利用の方が、また長距離出張であれば、テレビ会議の方が $\mathrm{SyLC}-\mathrm{CO}_{2}$ が小さく環境効率が 大さくなることが示される。さらに、テレビ会議の大幅普及に伴う新幹線の運行本数の変化が $\mathrm{CO}_{2}$ 排出量に及 ぼす影響も推計している。

\section{LCA Application Comparing the Eco-efficiency of Telemeetings and Face-to-face Meetings *}

$$
\text { By Ryoko MORIMOTO ** • Naoki SHIBAHARA *** • Naoki GOTO **** • Hirokazu KATO ***** }
$$

Information and communication technology has the potential to reduce the negative environmental effects of transportation activities. This study aims to investigate the possibility that telemeetings can reduce the load on the environment and also improve eco-efficiency. A framework for evaluating such a load includes the telemeeting system, transportation, and the rebound effect. It is found that telemeetings can indeed reduce environmental effects and improve eco-efficiency compared with typical business meetings that involve long distance trips by Shinkansen or air transport. Furthermore, the widespread use of telemeetings can bring about a change in the frequency of Shinkansen. 